\title{
PENGARUH CAR, BOPO, NPF DAN FDR TERHADAP ROA BANK SYARIAH PERIODE 2010 -2015
}

\author{
Yosi Stefhani \\ yosi.stefhani@yahoo.com
}

\begin{abstract}
Jurusan Manajemen, Fakultas Ekonomi, Universitas Satya Negara Indonesia Jalan Arteri Pondok Indah No.11 Jakarta Selatan
\end{abstract}

\begin{abstract}
The purpose of this study is to figure out the influence of CAR, BOPO, NPF and FDR on ROA Islamic Bank period 2010-2015. The population in this study are all Islamic Bank in Indonesia. Sampling technique used is purposive sampling. The sample in this study there are 11 Islamic Bank period 2010 to 2015. The data analysis method used is multiple regression analysis. The results showed that only BOPO has effect to ROA Islamic Bank. Three other variables CAR, NPF and FDR did not aff'ect the ROA Islamic Bank. The other result shown simultaneously CAR, ROA, NPF and FDR effect on ROA Islamic Bank.
\end{abstract}

Keywords: CAR, BOPO, NPL, FDR, ROA, Islamic Bank

\section{PENDAHULUAN}

Bank merupakan salah satu lembaga keuangan yang memiliki peranan dan fungsi penting dalam suatu sistem perekonomian. Lembaga keuangan pada umumnya dibedakan menjadi lembaga keuangan bank dan lembaga keuangan bukan bank yang memiliki peranan dan fungsi yang sama pentingnya juga. Sementara itu fungsi bank berdasarkan UU No.7 tahun 1992 tentang perbankan secara tegas menyebutkan bahwa fungsi utama bank adalah menghimpun dan menyalurkan dana dari masyarakat.

Perbankan Syariah mulai menjadi perhatian ketika banyak pihak mulai melirik konsep syariah dalam operasional bank dengan memperhatikan prinsip yang digunakan. Dilandasi oleh keyakinan bahwa perbankan syariah akan membawa kesejahteraan bagi peningkatan ekonomi dan pemerataan kesejahteraan masyarakat. Keyakinan ini didasari oleh berbagai alasan pertama, bank syariah lebih dekat dengan sektor riil karena produk yang ditawarkan, khususnya dalam pembiayaan, senantiasa menggunakan underlying transaksi di sektor riil sehingga dampaknya lebih nyata dalam mendorong pertumbuhan ekonomi. Kedua, tidak terdapat produk-produk yang bersifat spekulatif sehingga mempunyai daya tahan yang kuat dan teruji ketangguhannya dari krisis keuangan global. Hal ini telah banyak dibuktikan dengan berbagai hasil penelitian. Secara makro, perbankan syariah dapat memberikan daya dukung terhadap terciptanya stabilitas sistem keuangan dan perekonomian nasional. Ketiga, sistem bagi hasil (profit-loss sharing) yang menjadi ruh perbankan syariah akan membawa manfaat yang lebih adil bagi semua pihak, baik bagi pemilik dana selaku deposan, pengusaha selaku debitur maupun pihak bank selaku pengelola dana. 
Untuk itu pentingnya perbankan syariah untuk bisa menjaga kinerjanya. Kinerja perbankan bisa dilihat dari tingkat kesehatan bank itu sendiri. Berdasarkan Peraturan BI profitabilitas adalah salah satu unsur yang terutama dinilai dalam penentuan tingkat kesehatan bank. Banyak faktor yang dianggap mampu mempengaruhi profitabilitas bank syariah. Sama halnya dengan bank konvesional manajemen berusaha segala cara untuk meningkatkan profitabiltas bank baik dengan cara menekan biaya operasional, menekan pembiayaan yang bermasalah, meningkatkan modal yang ada dalam rangka meningkatkan penyaluran pembiayaan. Tapi pada kenyataan berbagai cara tersebut belum tentu dapat meningkatkan profitabilitas bank syariah. Contohnya data salah satu bank syariah dibawah ini :

Tabel 1

Indikator Kinerja Keuangan BNI Syariah

\begin{tabular}{|l|c|c|c|c|c|}
\hline \multicolumn{1}{|c|}{ Keterangan } & 2011 & 2012 & 2013 & 2014 & Description \\
\hline Tingkat Pengembalian Asset & $1,29 \%$ & $1,48 \%$ & $1,37 \%$ & $1,27 \%$ & Return on Assets \\
\hline $\begin{array}{l}\text { Rasio Kecukupan Modal } \\
\text { dengan Memperhitungkan } \\
\text { Risiko kredit }\end{array}$ & $20,75 \%$ & $19,29 \%$ & $16,54 \%$ & $18,76 \%$ & $\begin{array}{c}\text { Capital Adequacy Ratio } \\
\text { (CAR) to credit }\end{array}$ \\
\hline $\begin{array}{l}\text { Beban Operasional terhadap } \\
\text { Pendapatan Operasional }\end{array}$ & $87,86 \%$ & $85,39 \%$ & $83,94 \%$ & $85,03 \%$ & $\begin{array}{c}\text { Operation Expenses to } \\
\text { Operating Revenue }\end{array}$ \\
\hline $\begin{array}{l}\text { Pembiayaan Bermasalah } \\
\text { Bersih }\end{array}$ & $2,42 \%$ & $1,42 \%$ & $1,13 \%$ & $1,04 \%$ & NPF Net \\
\hline $\begin{array}{l}\text { Rasio Pembiayaan terhadap } \\
\text { dana Pihak Ketiga }\end{array}$ & $78,60 \%$ & $84,99 \%$ & $97,86 \%$ & $92,58 \%$ & Finance to Deposits (FDR) \\
\hline
\end{tabular}

Sumber : laporan tahunan BNI Syariah Tahun 2014

Dari tabel diatas terlihat indikator profitabilitas dengan melihat Return on Assets (ROA) pada tahun 2014 mengalami penurunan dibandingkan tahun 2013, padahal pembiayaan yang bermasalah dengan melihat indikator Net Performing Financing (NPF Net) mengalami penurunan. Seharusnya penurunan pembiayaan yang bermasalah mampu meningkatkan profitabilitas. Ditahun 2014 juga menunjukan adanya pertambahan modal dengan melihat indikator Capital Adequacy Ratio (CAR) yang tetap tidak bisa meningkatkan profitabilitas bank syariah tersebut. Sementara itu di tahun 2013 ROA juga mengalami penurunan dibandingkan tahun 2012, padahal biaya operasional dengan melihat indikator Biaya Operasional terhadap Pendapatan Operasional (BOPO) mengalami penuruan. Seharuskan adanya penurunan biaya operasional mampu meningkatkan profitabilitas bank syariah. Dan masih di tahun 2013 ada peningkatan penyaluran pembiayaan dengan melihat indikator Financing to deposits Ratio (FDR) yang meningkat tapi hal tersebut belum mampu meningkatkan profitabilitas bank syariah tersebut.

Penelitian-penelitian sebelumnya yang relevan terkait faktor-faktor yang mampu mempengaruhi profitabilitas bank telah dilakukan sebelumnya. Penelitian-penelitian sebelumnya masih menunjukan hasil penelitian yang berbeda. Berikut ini merupakan 
penelitian-penelitian sebelumnya terkait faktor-faktor yang mempengaruhi variabel ROA Bank Syariah.

\section{Tabel 2}

Research Gap

\begin{tabular}{|l|l|l|}
\hline Variabel & \multicolumn{1}{|c|}{ Peneliti } & \multicolumn{1}{c|}{ Hasil Penelitian } \\
\hline CAR & Gery & CAR berpengaruh terhadap ROA \\
\cline { 2 - 3 } & Imam Muklis & CAR berpengaruh terhadap ROA \\
\cline { 2 - 3 } & M.Sabir & CAR tidak berpengaruh terhadap ROA \\
\cline { 2 - 3 } & EdhiSatriyo W & CAR tidak berpengaruh terhadap ROA \\
\hline \multirow{4}{*}{ BOPO } & M.Sabir & BOPO berpengaruh terhadap ROA \\
\cline { 2 - 3 } & EdhiSatriyo W & BOPO berpengaruh terhadap ROA \\
\cline { 2 - 3 } & Gery & BOPO tidak berpengaruh terhadap ROA \\
\hline \multirow{5}{*}{ NPF } & AtikaRanianti & NPF berpengaruh terhadap ROA \\
\cline { 2 - 3 } & Imam Muklis & NPF tidak berpengaruh terhadap ROA \\
\cline { 2 - 3 } & Muh.Sabir & NPF tidak berpengaruh terhadap ROA \\
\cline { 2 - 3 } & EdhiSatriyo W & NPF tidak berpengaruh terhadap ROA \\
\hline \multirow{3}{*}{ FDR } & Muh. Sabir & FDR berpengaruh terhadap ROA \\
\cline { 2 - 3 } & Imam Muklis & FDR tidak berpengaruh terhadap ROA \\
\hline
\end{tabular}

Sumber :Dari Berbagai Jurnal Publikasi Ilmiah

Berdasarkan fenomena yang ada dan masih adanya perbedaan hasil penelitian sebelumnya maka penelitian selanjutnya terkait variabel apa saja yang mampu mempengaruhi profitabilitas bank syariah masih layak untuk dilakukan.

\section{KERANGKA PEMIKIRAN TEORITIS}

Berbagai faktor diidentifikasi mampu mempengaruhi profitabilitas (dengan indikator ROA) diantaranya adalah :

1. Inflasi. Inflasi adalah suatu proses meningkatnya harga-harga secara umum dan terus menerus (kontinyu) berkaitan dengan mekanisme pasar yang dapat disebabkan oleh berbagai faktor. Inflasi dapat berpengaruh buruk bagi perekonomian.

Hubungan inflasi dengan ROA. Apabila terjadi infasi yang parah tak terkendali maka keadaan perekonomian menjadi kacau dan perekonomian dirasakan lesu. Hal ini mengakibatkan minat masyarakat menabung atau berinvestasi menjadi berkurang. Inflasi mendorong meningkatnya tingkat suku bunga. Peningkatan suku bunga akan berpotensi menurunkan pertumbuhan pembiayaan yang dikeluarkan oleh bank. Hal ini dapat mengurangi pendapatan bank dan pada akhirnya berpotensi menurunkan laba bank.

2. Suku bunga. Bunga adalah imbal jasa atas pinjaman uang yang merupakan suatu kompensasi kepada pemberi pinjaman atas`manfaat ke depan dari uang pinjaman tersebut apabila diinvestasikan.

Hubungan Suku Bunga dengan ROA. Tingkat suku bunga jelas mampu mempengaruhi pertumbuhan pembiayaan yang dikeluarkan oleh bank jika tingkat suku bunga meningkat maka hal ini berpotensi menurunkan pendapatan yang berasal dari kegiatan pembiayaan yang dilakukan, penurunan pendapatan berpotensi akan menurunkan perolehan laba bank. 
3. Capital Adequacy Ratio (CAR) merupakan rasio permodalan yang menunjukkan kemampuan bank dalam menyediakan dana untuk keperluan pengembangan usaha serta menampung kemungkinan risiko kerugian yang diakibatkan dalam operasional bank. Perhitungan Capital Adequacy Ratio didasarkan pada prinsip bahwa setiap penanaman yang mengandung risiko harus disediakan jumlah modal sebesar persentase tertentu terhadap jumlah penanamannya.

Hubungan CAR dengan ROA. CAR mencerminkan modal sendiri perusahaan untuk menghasilkan laba. Semakin besar CAR maka semakin besar kesempatan bank dalam menghasilkan laba karena dengan modal yang besar, manajemen bank sangat leluasa dalam menempatkan dananya kedalam aktivitas investasi yang menguntungkan. Rendahnya CAR dikarenakan peningkatan ekspansi 4egat beresiko yang tidak diimbangi dengan penambahan modal menurunkan kesempatan bank untuk berinvestasi dan dapat menurunkan kepercayaan masyarakat kepada bank sehingga berpengaruh pada laba.

4. Biaya Operasional per Pendapatan Operasional (BOPO) merupakan rasio yang sering disebut rasio efisiensi ini digunakan untuk mengukur kemampuan manajemen bank dalam mengendalikan biaya operasional terhadap pendapatan operasional. Semakin rendah rasio BOPO berarti semakin baik kinerja manajemen bank tersebut, karena lebih efisien dalam menggunakan sumber daya yang ada di perusahaan.

Hubungan BOPO dengan ROA. Rasio BOPO menunjukkan efisiensi bank dalam menjalankan usaha pokoknya terutama pembiayaan. Pengelolaan pembiayaan sangat diperlukan oleh bank, mengingat fungsi pembiayaan sebagai penyumbang pendapatan terbesar bagi bank syariah. Semakin kecil BOPO menunjukkan semakin efisien bank dalam menjalankan aktivitas usahanya. Semakin tinggi biaya pendapatan bank berarti kegiatan operasionalnya semakin tidak efisien sehingga pendapatanya juga semakin kecil. Dengan kata lain BOPO berhubungan negatif terhadap laba bank.

5. Non Performing Fund (NPF). NPF adalah tingkat pengembalian pembiayaan yang diberikan deposan kepada bank dengan kata lain NPF merupakan tingkat pembiayaan macet pada bank tersebut. NPF diketahui dengan cara menghitung Pembiayaan Non Lancar Terhadap Total Pembiayaan. Apabila semakin rendah NPF maka bank tersebut akan semakin mengalami keuntungan, sebaliknya bila tingkat NPF tinggi bank tersebut akan mengalami kerugian yang diakibatkan tingkat pengembalian pembiayaan macet. Pembiayaan bermasalah yang terdiri dari pembiayan yang berklasifikasi Kurang Lancar, Diragukan dan Macet.

Hubungan NPF dengan ROA. NPF mencerminkan risiko pembiayaan, semakin tinggi rasio ini, menunjukkan kualitas pembiayaan bank syariah semakin buruk. Tingkat kesehatan pembiayaan (NPF) ikut mempengaruhi pencapaian laba bank. Semakin tinggi NPF akan membuat pendapatan semakin kecil dan laba semakin kecil.

6. Financing to Deposit Ratio (FDR). FDR digunakan untuk menilai likuiditas suatu bank dengan cara membagi jumlah pembiayaan dengan jumlah dana. Financing to Deposit Ratio (FDR) merupakan rasio yang menunjukkan kemampuan suatu bank dalam menyediakan dana kepada debiturnya dengan modal yang dimiliki oleh bank maupun dana yang dapat dikumpulkan dari masyarakat. Pembiayaan merupakan total pembiayaan yang diberikan kepada pihak ketiga (tidak termasuk antar bank). Dana Pihak Ketiga mencakup giro, tabungan, dan deposito (tidak termasuk antar bank).

Hubungan FDR dengan ROA. Salah satu ukuran untuk menghitung likuiditas bank adalah Financing to Deposit Ratio (FDR), yaitu seberapa besar dana bank dilepaskan 
ke perkreditan. Semakin tinggi Financing to Deposit Ratio (FDR), maka laba bank semakin meningkat (dengan asumsi bank tersebut mampu menyalurkan pembiayaan dengan efektif), dengan meningkatnya laba bank, maka kinerja bank juga meningkat. Sementara penelitian sebelumnya yang relevan yang telah dilakukan selama 5 tahun terakhir telah dilakukan. Berikut ini merupakan beberapa penelitian-penelitian tersebut.

Tabel 3

Penelitian Terdahulu yang Relevan

\begin{tabular}{|c|c|c|c|}
\hline Tahun & Peneliti & $\begin{array}{l}\text { Variabel Dan } \\
\text { Metode Analisis }\end{array}$ & Hasil Penelitian \\
\hline \multirow[t]{2}{*}{2015} & \multirow[t]{2}{*}{ Gery R } & $\begin{array}{l}\text { BOPO } \\
\text { CAR } \\
\text { ROA }\end{array}$ & \multirow{2}{*}{$\begin{array}{l}\text { 1. Secara simultan BOPO dan CAR } \\
\text { Berpengaruh terhadap ROA } \\
\text { 2. Secara partial BOPO tidak berpengaruh } \\
\text { terhadap ROA } \\
\text { 3. Secara partial CAR berpengaruh } \\
\text { terhadap ROA }\end{array}$} \\
\hline & & RegresiBerganda & \\
\hline \multirow[t]{2}{*}{2014} & \multirow[t]{2}{*}{$\begin{array}{l}\text { Atika R \& } \\
\text { Nirdukita R }\end{array}$} & $\begin{array}{l}\text { DPK } \\
\text { PYD } \\
\text { NPF } \\
\text { ROA }\end{array}$ & \multirow[t]{2}{*}{$\begin{array}{l}\text { 1. Secara simultan DPK, PYD, NPF } \\
\text { berpengaruh terhadap ROA } \\
\text { 2. PYD berpengaruh terhadap ROA } \\
\text { 3. DPK berpengaruh terhadap ROA } \\
\text { 4. NPF berpengaruh terhadap ROA }\end{array}$} \\
\hline & & $\begin{array}{l}\text { Structural } \\
\text { Equation Model } \\
\text { (SEM) }\end{array}$ & \\
\hline \multirow[t]{2}{*}{2013} & \multirow[t]{2}{*}{$\begin{array}{l}\text { EdhiSatriyo } \\
\text { W \&Sayichu }\end{array}$} & $\begin{array}{l}\text { CAR } \\
\text { BOPO } \\
\text { NPF } \\
\text { Inflasi } \\
\text { Bunga }\end{array}$ & \multirow{2}{*}{$\begin{array}{l}\text { 1. Secara simultan CAR, BOPO, NPF, } \\
\text { Inflasi dan Suku Bunga berpengaruh } \\
\text { terhadap ROA } \\
\text { 2. CAR tidak berpengaruh terhadap ROA } \\
\text { 3. BOPO berpengaruh terhadap ROA } \\
\text { 4. NPF tidak berpengaruh terhadap ROA } \\
\text { 5. Inflasi tidak berpengaruh terhadap } \\
\text { ROA } \\
\text { 6. Suku Bunga tidak berpengaruh } \\
\text { terhadap ROA }\end{array}$} \\
\hline & & RegresiBerganda & \\
\hline \multirow[t]{2}{*}{2012} & \multirow[t]{2}{*}{ Imam Muklis } & $\begin{array}{l}\text { CAR } \\
\text { NPF } \\
\text { FDR } \\
\text { INFLASI } \\
\text { GROWTH } \\
\text { ROA }\end{array}$ & \multirow[t]{2}{*}{$\begin{array}{l}\text { 1. Secara Simultan CAR, NPF, FDR, } \\
\text { INF, GR berpengauh terhadap ROA } \\
\text { 2. CAR berpengaruh terhadap ROA } \\
\text { 3. NPF tidak berpengaruh terhadap ROA } \\
\text { 4. FDR tidak berpengaruh terhadap ROA } \\
\text { 5. Inflasi tidak berpengaruh terhadap } \\
\text { ROA } \\
\text { 6. Growth berpengaruhterhadap ROA }\end{array}$} \\
\hline & & GLS Data Panel & \\
\hline
\end{tabular}




\begin{tabular}{|l|l|l|l|}
\hline 2012 & Muh.Sabir & CAR & 1. Secara simultan CAR, BOPO, NOM, \\
& et.al & BOPO & NPF, FDR berpengaruh terhadap ROA \\
& & 2. CAR tidak berpengaruh terhadap ROA \\
& NPF & 3. BOPO berpengaruh terhadap ROA \\
& FDR & 4. NOM berpengaruh terhadap ROA \\
& ROA & 5. NPF tidak berpengaruh terhadap ROA \\
\cline { 3 - 4 } & 6. FDR berpengaruh terhadap ROA
\end{tabular}

Sumber : Dari Berbagai Jurnal Publikasi Ilmiah

Berdasarkan penjelasan diatas maka dapat dikembangkan kerangka pemikiran teoritis seperti dibawah ini:

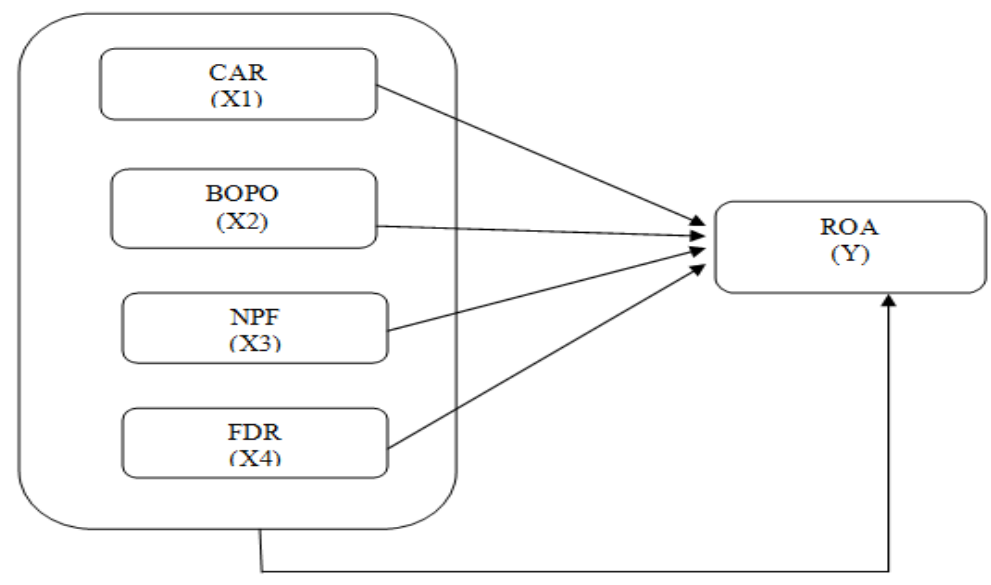

Gambar 1

Kerangka Pemikiran

Hipotesis yang diajukan dalam penelitian ini adalah :

Hipotesis 1:

Ho

: CAR tidak berpengaruh terhadap ROA

$\mathrm{Ha}$

: CAR berpengaruh terhadap ROA

Hipotesis 2:

Ho

: BOPO tidak berpengaruh terhadap ROA

$\mathrm{Ha}$

: BOPO berpengaruh terhadap ROA

Hipotesis 3:

Ho $\quad$ : NPF tidak berpengaruh terhadap ROA

$\mathrm{Ha} \quad$ : NPF berpengaruh terhadap ROA

Hipotesis 4:

Ho : FDR tidak berpengaruh terhadap ROA

Ha : FDR berpengaruh terhadap ROA

Hipotesis 5:

Ho : CAR, BOPO, NPF dan FDR secara simultan tidak berpengaruh terhadap ROA

Ha : CAR, BOPO, NPF dan FDR secara simultan FDR berpengaruh terhadap ROA 


\section{METODE}

\section{Populasi dan Sampel}

Populasi dalam penelitian ini adalah seluruh Bank Umum Syariah yang beroperasi di Indonesia. Adapun teknik penentuan sampling dalam penelitian ini adalah teknik sampel purpossive sampling yaitu sampel diambil berdasarkan kriteria tertentu. Adapun kriterianya adalah bank umum syariah yang memiliki laporan keuangan dan data keuangan yang dibutuhkan periode tahun 2010 sampai dengan 2014.

\section{Desain Penelitian}

Dalam penelitian ini desain penelitian yang digunakan yaitu Penelitian Kausal, yaitu penelitian yang bertujuan untuk mengetahui pengaruh antara satu atau lebih variabel independen terhadap variabel dependen.

\section{Jenis dan Sumber Data}

Jenis data yang digunakan dalam penelitian ini adalah data sekunder. Data yang berupa rasio rasio- keuangan Bank Umum Syariah hasil olahan laporan keuangan Bank Umum Syariah periode 2010-2015 yang telah diaudit dan kemudian dipublikasikan.

\section{Definisi Operasional Variabel dan Skala Pengukurannya}

Variabel penelitian dan definisi operasional berdasarkan pada masalah dan hipotesis yang akan di uji, yaitu sebagai berikut :

1. Variable Independen adalah variabel yang mempengaruhi perubahan dalam variabel terikat dan mempunyai hubungan yang positif atau negatif bagi variabel terikat lainnya. Variabel independen dalam penelitian ini berupa :

\section{a. CAR (Capital Adequacy Ratio) , X1}

Capital Adequacy Ratio merupakan rasio permodalan yang menunjukkan kemampuan bank dalam menyediakan dana untuk keperluan pengembangan usaha serta menampung kemungkinan risiko kerugian yang diakibatkan dalam operasional bank. Perhitungan Capital Adequacy Ratio didasarkan pada prinsip bahwa setiap penanaman yang mengandung risiko harus disediakan jumlah modal sebesar persentase tertentu terhadap jumlah penanamannya. Sejalan dengan standar yang ditetapkan Bank of International Settlements (BIS), seluruh bank yang ada di Indonesia diwajibkan untuk menyediakan modal minimum sebesar $8 \%$ dari ATMR.

Rumus Capital Adequacy Ratio (CAR) sebagai berikut :

$$
\text { CAR }=\frac{\text { Modal Sendiri }}{\text { ATMR }} \times 100 \%
$$

\section{b. BOPO (Biaya Operasional per Pendapatan Operasional), X2}

Rasio yang sering disebut rasio efisiensi ini digunakan untuk mengukur kemampuan manajemen bank dalam mengendalikan biaya operasional terhadap pendapatan operasional. Semakin rendah rasio BOPO berarti semakin baik kinerja manajemen bank tersebut, karena lebih efisien dalam menggunakan sumber daya yang ada di perusahaan. Rasio ini dirumuskan sebagai berikut (Surat Edaran Bank Indonesia No.6/23/DPNP tanggal 31 Mei 2004): 


\section{BOPO $=\frac{\text { Biaya Operasional }}{\times 100 \%}$ \\ Pendapatan Operasional}

\section{c. NPF (Non Performing Financing), X3}

NPF adalah tingkat pengembalian pembiayaan yang diberikan deposankepada bank dengan kata lain NPF merupakan tingkat pembiayaan macet pada bank tersebut. NPF diketahui dengan cara menghitung Pembiayaan Non Lancar Terhadap Total Pembiayaan. Apabila semakin rendah NPF maka bank tersebut akan semakin mengalami keuntungan, sebaliknya bila tingkat NPF tinggi bank tersebut akan mengalami kerugian yang diakibatkan tingkat pengembalian pembiayaan macet. Pembiayaan bermasalah yang terdiri dari pembiayaan yang berklasifikasi Kurang Lancar, Diragukan dan Macet.

$$
N P F=\frac{\text { PembiayaanBermasalah }}{\text { TotalPembiayaanYangDisalurkan }} \times 100
$$

\section{d. FDR (Financing to Deposit Ratio) , X4}

Financing to Deposit Ratio (FDR) digunakan untuk menilai likuiditas suatu bank dengan cara membagi jumlah pembiayaan dengan jumlah dana. Financing to Deposit Ratio (FDR) merupakan rasio yang menunjukkan kemampuan suatu bank dalam menyediakan dana kepada debiturnya dengan modal yang dimiliki oleh bank maupun dana yang dapat dikumpulkan dari masyarakat.

Rumus Financing to Deposit Ratio sebagai berikut :

$$
\mathrm{FDR}=\frac{\text { Pembiayaan }}{\text { Dana Pihak Ketiga }} \times 100
$$

Pembiayaan merupakan total pembiayaan yang diberikan kepada pihak ketiga (tidak termasuk antar bank). Dana Pihak Ketiga mencakup giro, tabungan, dan deposito (tidak termasuk antar bank).

Variabel Dependen adalah variabel yang dipengaruhi atau menjadi akibat karena adanya variabel independen. Variabel dependen dalam penelitian ini adalah Return on Assets (ROA), Y.

ROA adalah Rasio yang digunakan untuk mengukurkemampuan manajemen bank dalam memperoleh keuntungan secara keseluruhan. Semakin besar ROA suatu Bank, semakin besar pula tingkat keuntungan yang dicapai Banktersebut semakin baik pula posisi Bank tersebut dan penggunaan asset. Rasio ini dapat dirumuskan sebagai berikut:

$$
\text { ROA }=\underset{\text { Total Aktiva }}{\text { Laba Bersih }} \text { X } 100 \%
$$

Skala pengukuran untuk variabel-variabel dalam penelitian ini baik variabel independen maupun variabel dependen menggunakan skala ratio. Skala ratio adalah suatu skala yang merupakan penggabungan dari ketiga sifat skala lainnya. Skala rasio memiliki nilai nol mutlak dan datanya dapat dikalikan atau dibagi. 


\section{Metode Analisis data}

\section{Analisis deskriptif}

Metode analisis deskriptif merupakan metode yang digunakan untuk menganalisis datadata yang tersedia dan diolah sehingga diperoleh gambaran yang jelas mengenai faktafakta fenomena yang diteliti.

2. Analisa regresi berganda

Model regresi linier dikatakan sebagai model yang baik hanya jika model tersebut memenuhi asumsi-asumsi klasik yaitu data residual terdistribusi normal, tidak adanya multikolinieritas, autokorelasi dan heterokedastisitas.

\section{Uji Asumsi Klasik}

\section{- Uji Normalisasi}

Uji ini bertujuan untuk menguji apakah data yang digunakan telah terdistribusi normal. Model regresi yang baik adalah yang memiliki data terdistribusi normal.Menguji normalitas data, dapat dilihat pada grafik probability plot. Data dapat dikatakan normal bila data atau titik titik tersebar disekitar garis diagonal dan penyebarannya mengikuti garis diagonalnya. Metode yang lebih akurat untuk menguji normalitas adalah dengan uji Kolmogorov Smirnov, yaitu dengan melihat angka nilai signifikansinya lebih dari 0.05 .

\section{- Uji Multikolonieritas}

Uji multikolonieritas bertujuan untuk menguji apakah model regresi ditemukan adanya korelasi antar variabel bebas. Model regresi yang baik seharusnya tidak terjadi korelasi diantara variabel bebas. Untuk mendeteksi ada atau tidaknya gejala multikolinieritas dalam suatu model regresi dapat diketahui dari Variance Inflation Factor (VIF) apabila nilai VIF kurang dari 10 dan Tolerance lebih dari 0,1 maka dinyatakan tidak terjadi multikolinieritas.

\section{- Uji Autokorelasi}

Uji ini bertujuan untuk menguji apakah dalam model regresi linier ada korelasi antara kesalahan pengganggu pada periode $t$ dengan kesalahan pengganggu pada periode $t-1$ (sebelumnya). Pengujian ada tidaknya autokorelasi dalam persamaan ini digunakan uji Durbin Watson (DW - test). Model regresi yang baik adalah model yang tidak mengandung autokorelasi. Pengambilan keputusan pada uji Durbin Watson sebagai berikut :

a. $\quad \mathrm{DU}<\mathrm{DW}<4$-DU maka $\mathrm{H}_{0}$ diterima, artinya tidak terjadi autokorelasi.

b. DW $<$ DL atau DW $>4$-DL maka $\mathrm{H}_{0}$ ditolak, artinya terjadi autokorelasi.

c. DL $<$ DW $<$ DU atau 4 -DU $<$ DW $<4-$ DL, artinya tidak ada kepastian atau kesimpulan yang pasti.

\section{- Uji Heteroskedastisitas}

Uji heteroskedastisitas bertujuan untuk menguji apakah dalam sebuah model regresi terjadi ketidaksamaan varians dari suatu pengamatan ke pengamatan yang lain. Model regrasi yang baik adalah seharusnya tidak terjadi heteroskedastisitas. Uji heteroskedastisitas bisa dengan melihat pola titik-titik pada grafik regresi. Jika tidak ada pola yang jelas, seperti titik-titik menyebar di atas dan dibawah angka 0 pada sumbu Y, maka tidak terjadi heteroskedastisitas, 


\section{Analisis Regresi Linear Berganda}

Metode analisis regresi linear berganda merupakan suatu bentuk hubungan linear antara dua atau lebih variabel independen dengan veriabel dependennya.

1. Uji F

Uji ini merupakan pengujian untuk pengaruh dari variabel-variabel independen secara simultan terhadap variabel dependen. Dalam pengujian ini sebelumnya dirumuskan hipotesisnya.

Ho : Variabel-Variabel Independen secara simultan tidak berpengaruh terhadap variabel dependen

Ha : Variabel- variabel Independen secara simultan berpengaruh terhadap variabel dependen

Kriteria pengujian untuk uji $\mathrm{F}$ berdasarkan signifikansi sebagai berikut :

Jika Signifikansi > 0,05 maka Ho diterima

Jika Signifikansi $<0,05$ maka Ho ditolak

2. Uji t

Digunakan untuk membuktikan pengaruh variabel independen terhadap variabel dependen secara individu atau parsial. Dalam pengujian ini sebelumnya dirumuskan hipotesisnya.

Ho : Variabel Independen tidak berpengaruh terhadap variabel dependen

Ha : Variabel Independen berpengaruh terhadap variabel dependen

Kriteria pengujian untuk uji t berdasarkan signifikansi sebagai berikut:

Jika Signifikansi > 0,05 maka Ho diterima

Jika Signifikansi $<0,05$ maka Ho ditolak

2. Koefisien determinasi $\left(\mathrm{R}^{2}\right)$

Koefisien determinasi $\left(\mathrm{R}^{2}\right)$ pada intinya mengukur seberapa jauh kemampuan model dalam menerangkan variasi variabel terikat. Besarnya nilai koefisien determinasi adalah di antara nol dan satu $(0<\mathrm{R} 2<1)$.

3. Model Regresi Berganda dalam penelitian ini adalah sebagai berikut:

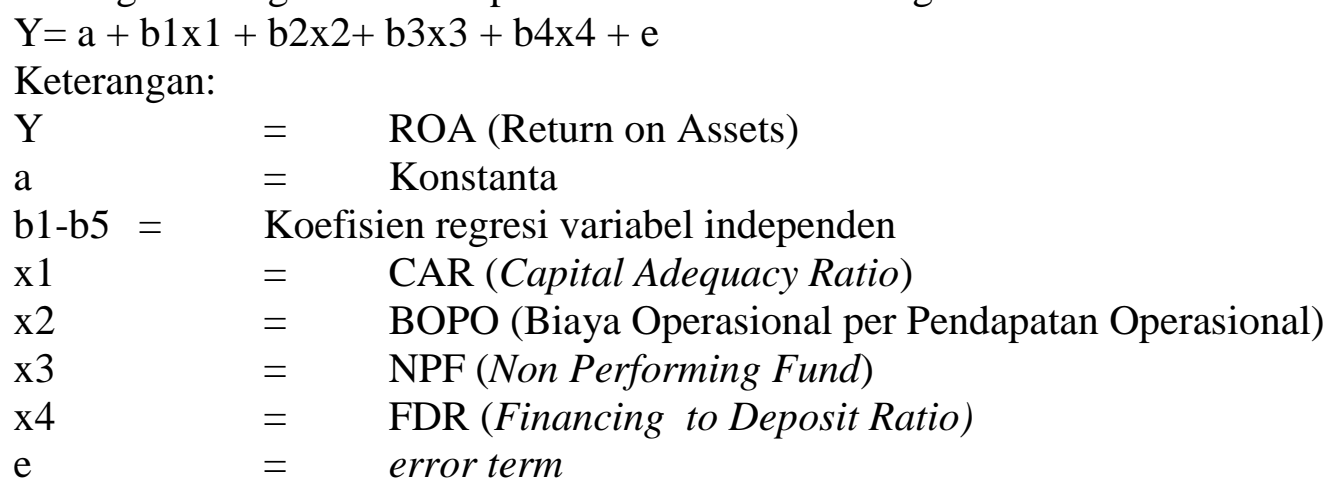

\section{PEMBAHASAN}

Pengolahan data dalam penelitian ini menggunakan analisis regresi berganda sehingga seluruh data harus melewati uji asumsi klasik terlebih dahulu.Pengujian asumsi klasik bertujuan untuk menghasilkan model regresi yang baik. Dengan demikian dalam penelitian ini menggunakan 66 observasi, tetapi dari seluruh observasi ini terdapat 26 observasi yang dikeluarkan dari pengamatan (outlier) kerena tiap variabel memiliki nilai yang terlalu tinggi atau terlalu rendah (ekstrim) sehingga total observasi dalam penelitian ini berjumlah 40 observasi. 


\section{Uji Asumsi Klasik}

\section{Hasil Uji Normalitas}

Pengujian normalitas data dalam penelitian ini menggunakan uji KolmogorovSmirnov. Dengan membandingkan nilai signifikan yang dicapai dengan taraf signifikansi yang sudah ditentukan yaitu 0,05 . Berikut ini merupakan hasil uji normalitas:

Tabel 4

Uji Normalitas

\begin{tabular}{|l|r|r|r|}
\hline \multirow{2}{*}{} & \multicolumn{3}{|c|}{ Kolmogorov-Smirnov $^{\mathrm{a}}$} \\
\cline { 2 - 4 } & Statistic & Df & \multicolumn{1}{c|}{ Sig. } \\
\hline CAR & .134 & 40 & .068 \\
BOPO & .097 & 40 & $.200^{*}$ \\
NPF & .109 & 40 & $.200^{*}$ \\
FDR & .118 & 40 & .166 \\
ROA & .090 & 40 & $.200^{*}$ \\
\hline
\end{tabular}

Sumber : Hasil Pengolahan Data

Dari hasil pengujian terlihat bahwa nilai signifikan yang diperoleh melebihi taraf signifikan yang telah ditentukan yaitu 0,05 sehingga menunjukan bahwa data-data dalam penelitian ini terdistribusi normal.

\section{Hasil Uji Multikolinieritas}

Pengujian multikolinieritas dalam penelitian ini dengan cara meregresikan model analisis dan melakukan uji korelasi antar variabel independen dengan menggunakan Tolerance dan Varians Inflating Factor (VIP). Berikut ini merupakan hasil uji multikolinieritas :

Tabel 5

Uji Multikolinieritas

\begin{tabular}{|ll|r|r|}
\hline \multirow{2}{*}{ Model } & & \multicolumn{2}{|c|}{ Collinearity Statistics } \\
\cline { 3 - 4 } & & \multicolumn{1}{|c|}{ Tolerance } & \multicolumn{1}{c|}{ VIF } \\
\hline 1 & (Constant) & & \\
& CAR & .613 & 1.632 \\
& BOPO & .498 & 2.008 \\
& NPF & .429 & 2.334 \\
& FDR & .907 & 1.103 \\
\hline
\end{tabular}

Sumber : Hasil Pengolahan Data

Dari hasil pengujian terlihat bahwa nilai Tolerance lebih dari 0,1 dan VIF kurang dari 10 maka dinyatakan tidak terjadi multikolinieritas.

\section{Hasil Uji Autokorelasi}

Pengujian autokorelasi dalam penelitian ini menggunakan uji Durbin-Watson. Berikut ini merupakan hasil uji Autokorelasi 
Tabel 6

Uji Autokorelasi

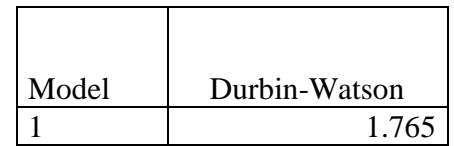

Sumber : Hasil Pengolahan Data

Hasil pengujian menunjukan nilai DW 1,765 sedangkan nilai DL dan DU dilihat dari tabel statistik Durbin-Watson dengan $\mathrm{n}=40$ dan $\mathrm{k}=4$ maka diperoleh DL 1,2848 dan DU 1,7209. Maka nilai 4- DU $=2,2791$ sementara nilai DW 1,765. Sehingga $\mathrm{DU}<\mathrm{DW}<4-\mathrm{DU}$ atau $1,7209<1,765<2,2781$, artinya model regresi dalam penelitian tidak terjadi autokorelasi.

\section{Hasil Uji Heteroskedastisitas}

Pengujian heteroskedastisitas dalam penelitian ini dengan melihat Scatterplot. Berikut ini merupakan hasil uji Autokorelasi:

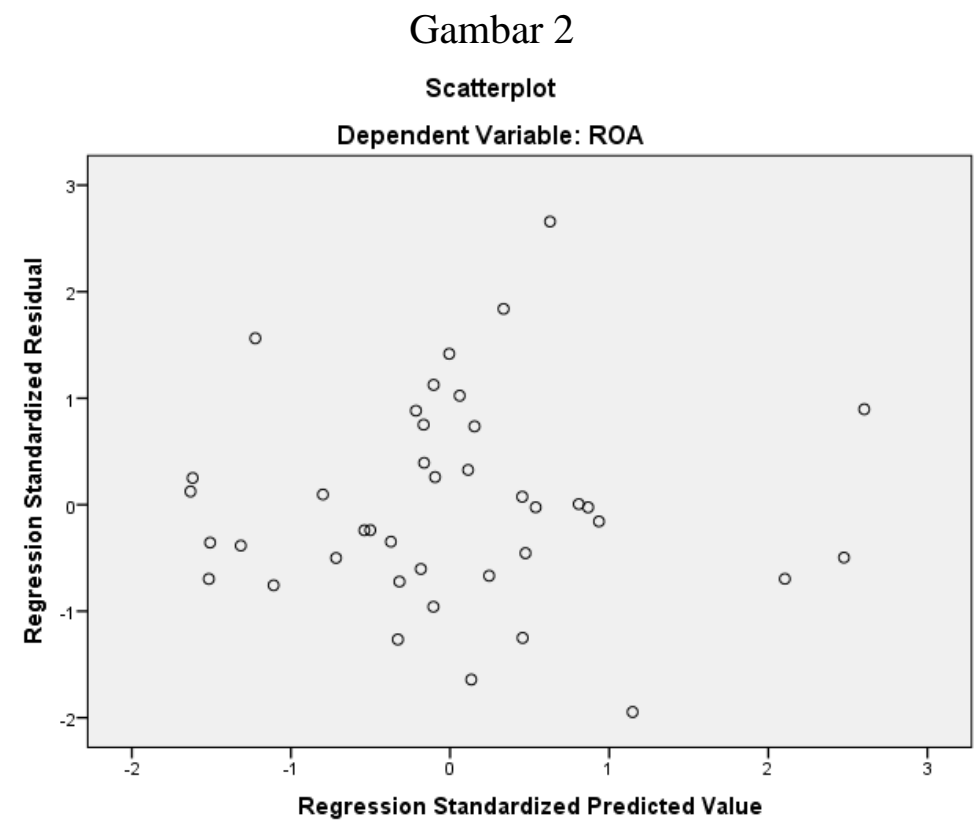

Sumber : Hasil Pengolahan Data

Hasil pengujian uji heteroskedastisitas diatas terlihat tidak ada pola yang jelas, dimana titik-titik menyebar di atas dan dibawah angka 0 pada sumbu Y, maka ini menunjukan tidak terjadi heteroskedastisitas,

Setelah melakukan pengujian asumsi klasik, langkah berikutnya melakukan pengujian hipotesis dengan menggunakan uji regresi berganda. 


\section{Uji Regresi Berganda}

\section{Hasil Uji F}

Uji F (Uji Simultan) adalah untuk melihat pengaruh variabel bebasterhadapvariabel terikatnya secara simultan. Untuk melihat hasilpengujian dapat dilihat pada tabel Anova. Berikut adalah nilai $\mathrm{F}$ hitungdansignifikansi dalam tabel 7 untuk penelitian ini:

Tabel 7

Uji F

\begin{tabular}{|ll|r|r|r|r|r|}
\hline Model & & Sum of Squares & Df & Mean Square & F & Sig. \\
\hline 1 & Regression & 10.405 & 4 & 2.601 & 22.435 & $.000^{\mathrm{b}}$ \\
& Residual & 4.058 & 35 & .116 & & \\
& Total & 14.463 & 39 & & & \\
\hline
\end{tabular}

a. Dependent Variable: ROA

b. Predictors: (Constant), FDR, CAR, BOPO, NPF

Sumber : Hasil Pengolahan Data

Hasil pengujian uji $\mathrm{F}$ menunjukan nilai signifikan yang diperoleh adalah 0,000 berarti lebih kecil dari tingkat signifikansi 0,05. Karena nilai sig lebih kecil dari 0,05 maka Ho ditolak. Sehingga dapat disimpulkan bahwa CAR, BOPO, NPF, FDR secara simultan berpengaruh terhadap ROA.

\section{Hasil Uji t}

Uji t (Uji Parsial) digunakan untuk melihat pengaruh variabel-variabel bebassecara parsial terhadap variabel terikatnya.untuk melihat hasil pengujian dapat melihat table Coefficients. Berikut ini adalah hasilpengitungan nilai t hitung dan taraf signifikannya dalam tabel 8 untuk penelitian ini:

Tabel 8

Uji t

\begin{tabular}{|c|c|c|c|c|c|}
\hline \multirow[b]{2}{*}{ Model } & \multicolumn{2}{|c|}{ Unstandardized Coefficients } & \multirow{2}{*}{$\begin{array}{c}\text { Standardized } \\
\text { Coefficients } \\
\text { Beta } \\
\end{array}$} & \multirow[b]{2}{*}{$\mathrm{t}$} & \multirow[b]{2}{*}{ Sig. } \\
\hline & B & Std. Error & & & \\
\hline $1 \quad$ (Constant $)$ & 8.985 & .966 & & 9.299 & .000 \\
\hline CAR & -.012 & .012 & -.120 & -1.046 & .303 \\
\hline BOPO & -.082 & .013 & -.829 & -6.534 & .000 \\
\hline NPF & .020 & .067 & .040 & .295 & .770 \\
\hline FDR & -.004 & .006 & -.065 & -.695 & 492 \\
\hline
\end{tabular}

Sumber : Hasil Pengolahan Data

Hasil pengujian uji t menunjukan nilai signifikan untuk setiap variabel independen. Dari 4 variabel independen hanya satu variabel independen yaitu BOPO yang nilai signifikansi lebih kecil dari 0,05 maka Ho ditolak. Sementara itu 3 variabel independen lainnya yaitu CAR, NPF, FDR memperoleh nilai signifikansinya lebih besar dari 0,05 maka Ho diterima. Dengan hasil pengujian ini maka dapat simpulkan bahwa hanya variabel BOPO 
yang berpengaruh terhadap ROA, sementara CAR, NPF, FDR tidak berpengaruh terhadap ROA.

\section{Uji Koefisien determinasi $\left(\mathbf{R}^{2}\right)$}

Untuk mengetahui besar pengaruh variabel bebas secara simultan berpengaruh terhadap variabel terikat dengan melihat nilai $R$-Squarepada tabel 9 Model Summery berikut:

Tabel 9

R-Square

Model Summary

\begin{tabular}{|l|r|r|r|}
\hline Model & R & R Square & \multicolumn{1}{c|}{$\begin{array}{c}\text { Adjusted R } \\
\text { Square }\end{array}$} \\
\hline 1 & $.848^{\mathrm{a}}$ & .719 & .687 \\
\hline
\end{tabular}

Sumber : Hasil Pengolahan Data

Dari hasil pengolahan data menunjukan $\mathrm{R}^{2}$ ( $\mathrm{R}$ Square) menunjukan bahwa 0,719 berarti sekitar $71,9 \%$ dari variabel perubahan ROA dapat dijelaskan oleh variabel independennya.

\section{Persamaan Regresi}

Berdasarkan hasil pada tabel Coefficients tersebut, dapat disusunpersamaan regresi linier berganda sebagai berikut:

Tabel 10

Coefficients $^{\mathrm{a}}$

\begin{tabular}{|c|c|c|c|c|c|c|}
\hline \multirow[b]{2}{*}{ Mod } & & \multicolumn{2}{|c|}{ Unstandardized Coefficients } & \multirow{2}{*}{$\begin{array}{c}\text { Standardized } \\
\text { Coefficients }\end{array}$} & \multirow[b]{2}{*}{$\mathrm{t}$} & \multirow[b]{2}{*}{ Sig. } \\
\hline & & $\mathrm{B}$ & Std. Error & & & \\
\hline \multirow[t]{5}{*}{1} & (Constant) & 8.985 & .966 & & 9.299 & .000 \\
\hline & CAR & -.012 & .012 & -.120 & -1.046 & .303 \\
\hline & BOPO & -.082 & .013 & -.829 & -6.534 & .000 \\
\hline & NPF & .020 & .067 & .040 & .295 & .770 \\
\hline & FDR & -.004 & .006 & -.065 & -.695 & .492 \\
\hline
\end{tabular}

a. Dependent Variable: ROA

$$
Y=8,985-0,012 X_{1}-0,082 X_{2}+0,020 X_{3}-0,004 X_{4}
$$

\section{Perbandingan Hasil Penelitian dengan Teori}

1. Semakin tinggi CAR maka semakin kuat kemampuan bank tersebut utnuk menanggung resiko dari setiap kredit/aktiva produktif yang berisiko. Jika nilai CAR tinggi (sesuai ketentuan BI 8\%) berarti bank tersebut mampu membiayai operasi bank, keadaan yang menguntungkan bank tersebut akan memberikan kontribusi yang cukup besar bagi profitabilitas. Hasil penelitian menunjukan CAR tidak berpengaruh terhadap ROA. Hasil penelitian ini tidak sesuai dengan teori yang menyatakan bahwa CAR berpengaruh ROA. Asumsi argumentasi untuk hal ini diantaranya sampel yang digunakan dalam penelitian ini mempunyai nilai rata-rata yang relatif rendah 
dibandingkan dengan nilai rata-rata populasinya. Nilai rata-rata populasi CAR adalah 28,29 sementara nilai rata-rata sampel penelitian hanya sebesar 17,48.

2. BOPO merupakan perbandingan antara biaya operasional dengan pendapatan operasonal. Rasio ini digunakan untuk mengukur kemampuan bank dalam hal dalam melakukan efisiensi dalam kegiatan operasionalnya. Hasil penelitian menunjukan BOPO berpengaruh terhadap ROA. Hasil penelitian ini sesuai dengan teori yang menyatakan bahwa BOPO mempunyai pengaruh terhadap ROA.

3. Non Performing Financing adalah perbandingan antara total pembiayaan bermasalah dengan total pembiayaan yang di berikan kepada nasabah. Bank dikatakan mempunyai NPF yang tinggi jika banyaknya pembiayan yang bermasalah lebih besar daripada jumlah pembiayaan yang diberikan kepada nasabah. Apabila suatu bank mempunyai NPF yang tinggi, maka akan memperbesar biaya, baik biaya pencadangan aktiva produktif maupun biaya lainnya, dengan kata lain semakin tinggi NPF suatu bank, maka hal tersebut akan mengganggu kinerja bank tersebut. Hasil penelitian menunjukan NPF tidak berpengaruh terhadap ROA. Hasil penelitian ini tidak sesuai dengan teori yang menyatakan bahwa NPF berpengaruh ROA. Asumsi argumentasi untuk hal ini tingkat keuntungan atau laba yang diperoleh oleh bank tidak hanya semata-mata dari faktor NPF tapi bisa jadi dari biaya operasional yang tinggi. Data sebelumnya menunjukan adanya peningkatan BOPO secara tajam di tiga tahun terakhir.

4. Financing to Deposit Ratio (FDR) merupakan kemampuan bank dalam menyediakan dana dan menyalurkan dana kepada nasabah, dan memiliki pengaruh terhadap profitabilitas. Nilai FDR menunjukkan efektif tidaknya bank dalam menyalurkan pembiayaan, apabila nilai FDR menunjukkan prosentase terlalu tinggi maupun terlalu rendah maka bank dinilai tidak efektif dalam menghimpun dan menyalurkan dana yang diperoleh dari nasabah, sehingga mempengaruhi laba yang didapat. FDR tidak berpengaruh terhadap ROA. Hasil penelitian ini tidak sesuai dengan teori yang menyatakan bahwa FDR berpengaruh ROA. Asumsi argumentasi untuk hal ini diantaranya FDR yang tinggi tidak menjamin tingkat pengembalian menjadi tinggi dalam hal ROA, karena pembiayaan yang besar tanpa pengembalian yang lancar dan pengelolaan biaya yang efisien potensi memperoleh laba tinggi sulit untuk tercapai.

5. Hasil penelitian yang terakhir menunjukan CAR, BOPO, NPF dan FDR secara simultan bepengaruh terhadap ROA. Hasil penelitian ini menunjukan kesesuaian dengan teori.

\section{Perbandingan Hasil Penelitian dengan Penelitian Sebelumnya}

Hasil penelitian ini kemudian dibandingkan dengan penelitian sebelumnya yang relevan yang telah disebutkan di bab 2. Berikut hasil perbandingan hasil penelitian dengan penelitian sebelumnya. 
Tabel 11

Perbandingan Hasil Penelitian dengan Penelitian Sebelumnya

\begin{tabular}{|c|c|c|c|}
\hline No. & Hasil Penelitian & \multicolumn{2}{|c|}{ Penelitian Sebelumnya } \\
\hline & & Konsisten & Tidak Konsisten \\
\hline 1. & $\begin{array}{l}\text { CAR tidak berpengaruh } \\
\text { terhadap ROA }\end{array}$ & $\begin{array}{ll}\text { 1. } & \text { Edhi Satriyo W \& } \\
& \text { Sayichu (2013) } \\
\text { 2. } & \text { Muh.Sabir et.al (2012) }\end{array}$ & $\begin{array}{l}\text { 1. Gery R (2015) } \\
\text { 2. Imam Muklis } \\
\text { (2012) }\end{array}$ \\
\hline 2. & $\begin{array}{l}\text { BOPO berpengaruh } \\
\text { terhadap ROA }\end{array}$ & $\begin{array}{l}\text { 1. } \\
\text { Edhi Satriyo W \& } \\
\text { Sayichu (2013) } \\
\text { 2. } \text { Muh.Sabir et.al (2012) }\end{array}$ & 1. Gery R (2015) \\
\hline 3. & $\begin{array}{l}\text { NPF tidak berpengaruh } \\
\text { terhadap ROA }\end{array}$ & $\begin{array}{ll}\text { 1. } & \text { Edhi Satriyo W } \\
& \& \text { Sayichu (2013) } \\
\text { 2. } & \text { Imam Muklis (2012) } \\
\text { 3. } & \text { Muh.Sabir et.al (2012) }\end{array}$ & $\begin{array}{l}\text { 1. } \\
\text { Atika R \& } \\
\text { Nirdukita R (2014) }\end{array}$ \\
\hline 4. & $\begin{array}{l}\text { FDR tidak berpengaruh } \\
\text { terhadap ROA }\end{array}$ & 1. Imam Muklis (2012) & $\begin{array}{l}\text { 1. Muh.Sabir et.al } \\
\text { (2012) }\end{array}$ \\
\hline 5. & $\begin{array}{l}\text { CAR, BOPO, NPF dan FDR } \\
\text { secara simultan bepengaruh } \\
\text { terhadap ROA }\end{array}$ & $\begin{array}{ll}\text { 1. } & \text { Gery R (2015) } \\
\text { 2. } & \text { Atika R \& Nirdukita R } \\
& (2014) \\
\text { 3. } & \text { Edhi Satriyo W } \\
& \text { \&Sayichu (2013) } \\
\text { 4. } & \text { Imam Muklis (2012) } \\
\text { 5. } & \text { Muh.Sabir et.al (2012) }\end{array}$ & \\
\hline
\end{tabular}

\section{PENUTUP}

Berdasarkan hasil analisis data maka dapat ditarik kesimpulan bahwa hanyavariabel BOPO yang mampu mempengaruhi ROA bank syariah. Sementara itu CAR, NPF dan FDR tidak berpengaruh terhadap ROA bank syariah.

Saran yang bisa diberikan oleh peneliti bagi (1) penelitian selanjutnyamencari variabel independen lain diluar variabel independen yang peneliti gunakan untuk memastikan sebenarnya variabel-variabel apa saja yang berpengaruh terhadap ROA. Hal ini penting dilakukan mengingat ROA merupakan indikator dari variabel profitabilitas yang sangat pening baik setiap jenis usaha apapun termasuk Bank dan menggunakan indikator lain selain ROA yang lebih tepat sebagai indikator profitabilitas dalam meneliti tentang faktor-faktor apa saja yang mempengaruhi profitabilitas Bank Syariah sebagai perbandingan dengan penelitian ini. (2) Manajemen Bank Syariah karena berdasarkan hasil penelitian karena hanya BOPOyang berpengaruh terhadap ROA maka sebaiknya manajemen betul-betul 
memperhatikan pengelolaan biaya operasional kegiatan usahanya dan lebih meningkatkan lagi dalam rangka efisisensi biaya operasional kegiatan usaha Bank Syariah.

\section{DAFTAR PUSTAKA}

Dewi, Kadek Krismaya dan IGA M.Asri Dwijaputri. "Pengaruh Penerapan Prinsip-Prinsip GCG Pada Kinerja Keuangan Lembaga Perkreditan Desa Kabupaten Gianyar Bali”. EJurnal Akutansi Universitas Udayana 7.3 (2014):559-573.

Faiz, Ihza A. "Ketahanan Kredit Perbankan Syariah Terhadap Krisis Keuangan Global". La_Riba, Jurnal Ekonomi IslamVolume IV, No.2 Desember (2010) : 217-237.

Jefriando, Maikel. "Menkeu Bambang; Bank Syariah Lebih Tahan Banting Menghadapi Krisis", detikFinance, Selasa 14 April 2015, http://www.tipsiana.com/2015/04/inilah10-krisis-moneter-terburuk-dalam.html (diakses 5 Januari 2016)

Kuncoro, Mudrajad. “ Metode Riset untuk Bisnis dan Ekonomi”, (Jakarta, Erlangga, 2014)

Manihuruk, Jonggi. "Konspirasi di Balik Cessie Bank Bali," Media Indonesia, Senin, 23 November 2015,http://www.mediaindonesia.com/mipagi/read/17294/Konspirasi-diBalik-Cessie-Bank-Bali (diakses 5 Januari 2016).

Maisaroh dan Ati Sumiati." Tantangan dan Peluang Perbankan Syariah dalam Pengembangan Usaha Kecil dan Menengah untuk Memperkuat Kesejahteraan Umat". Econo Sains Volume IX, Nomor 2, Agustus (2011): 133-145.

Muklis, Imam.” Kinerja Keuangan Bank dan Satbilitas Makro ekonomi Terhadap Profitabilitas Bank Syariah di Indonesia”, Jurnal Keuangan dan perbankan, Vol 16, No.2 Mei (2012), hlm 275-285 .

OJK : Potensi Pertumbuhan Ekonomi ditinjau dari Penyaluran Kredit Perbankan Kepada Sektor Prioritas Ekonomi Pemerintah, (Jakarta, Departemen Pengembangan Pengawasan dan Manajemen Krisis, 2015), 1.

Putri, Yudiana Febrita dkk. "Analisis Perbandingan Kinerja Keuangan Bank Konvensional dan bank Syariah” JEAM, Vol XIV, April (2015) : 27-42

Sabir, Muh et al." Pengaruh Rasio Kesehatan Bank Terhadap Kinerja Keuangan Bank Umum Syariah dan Bank Konvensional di Indonesia”, Jurnal Analisis, Juni 2012, Vol.1 No.1 : $79-86$.

Santoso , A. Totok Budi dan Nuritomo“ Bank dan Lembaga Keuangan Lain” , Edisi 3, (Jakarta, Salemba Empat, 2014), 7.

Satriyo, Edhi Wibowo dan Sayichu." Analisa Pengaruh Suku Bunga, Inflasi, CAR, BOPO, NPF Terhadap Profitabilitas Bank Syariah", Journal of Management, Volume 2, Nomor 2, Tahun 2013, Halaman 1-10.

Sidik, Jafar M. “ Krisis Ekonomi Asia Sekarang Tak seburuk Krisis Moneter 1997" AntaraNews, Senin, 24 Agustus 2015,http://www.antaranews.com/berita/514156/krisis-ekonomi-asia-sekarang-takseburuk-krisis-moneter-1997 (diakses 5 Januari 2016).

Ranianti , Atika dan Nirdukita Ratnawati."Pengaruh Pembiayaan Dana Pihak Ketiga dan Non Performing Financing Terhadap Return on Assets Perbankan Syariah Di 
Indonesia 2009-2013”, Jurnal Ekonomi Pembangunan Trisakti (e-Journal),Volume. 1 Nomor. 2 Februari 2014, Hal. 109-128.

Rendiana, Gery. "Analisis Pengaruh efisiensi (BOPO) dan Capital Adequacy Ratio (CAR)

Terhadap Renturn on Assets (ROA) (Studi Kasus Pada Perbakan Syariah yang Terdaftar di OJK pada tahun 2010-2014), Prosisding Penelitian Civitas Unisba (2015).

Uyanto, Stanislaus S. "Pedoman Analisis Data dengan SPSS", (Yogyakarta, Graha Ilmu, 2008), 218.

Wibowo, Edhi Satriyo dan Muhammad Sayichu. "Analisis Pengaruh Suku Bunga, Inflasi,

CAR, BOPO, NPF Terhadap Profitabilitas Bank Syariah “. Diponegoro Journal Of

Managemen", Volume 2, Nomor 2, (2013): 1-10.

Wibowo, Pungky Purnomo. "Banchless Banking Setelah Multilincense:Ancaman Atau

Kesempatan bagi Perbakan Nasional" (Jakarta: Bank Indonesia,2013), hal iii.

Yahya, Muchis dan Edy Yusuf Agunggunanto, “ Teori Bagi Hasil (Profit and Loss Sharing) dan Perbankan Syariah dalam Ekonomi Syariah”, Jurnal Dinamika Ekonomi Pembangunan, Volume 1, Nomor 1 Juli (2011): 65-73.

"'Inilah Krisis Moneter Terburuk Dalam Sejarah"Senin, 20 April 2015, http://www.tipsiana.com/2015/04/inilah-10-krisis-moneter-terburuk-dalam.html(

diakses 5 Januari 2016).

"Undang-Undang No.7 Tahun 1992 tentang Perbankan", (pasal 2, 1992), hal 3.

Laporan Keuangan Bank BNI Tahun (2014).

Laporan Perbankan Syariah, Bank Indonesia (2012).

Lampiran 2d Surat Edaran Bank Indonesia No.6/23/DPNP tanggal 31 Mei 2004.

Peraturan Bank Indonesia No.11/10/PBI/2009 tentang Unit Usaha Syariah.

Peraturan Bank Indonesia No.12/19/PBI/2010

Peraturan Bank Indobesia No.15/12/PBI/2013 tentang Kewajiban Penyediaan Modal Minimum Bank Umum. 